\title{
Judges Existencing In The Judicial Process Of Narcotics Criminal Actors
}

\section{Diyono*) and Amin Purnawan $^{* *}$}

${ }^{*}$ Student of Master of Law, Faculty of Law, Universitas Islam Sultan Agung (UNISSULA) and Indonesian Army of Magelang City, email: diyono.sh.mh@gmail.com

$\left.{ }^{* *}\right)$ Faculty of Law, Universitas Islam Sultan Agung (UNISSULA) Semarang

\begin{abstract}
Aim in this study, namely to study and analyze the existence of judges in the trial of narcotics offenders? In this study the authors used a sociological juridical method with a descriptive analytical research specification. The data used for this research are primary and secondary data. Based on the results of the research with the conclusion that the existence of judges in the implementation of the narcotics crime court based on the analysis in case Number 70 / Pid.Sus / 2018 / PN Mgg, it is not wrong to be categorized as someone who thinks scientifically. As seen in the decision making, where the judge does not solely work to make and determine decisions by observing and completely applying abstract legal rules, but judges always see the problems faced in a broader context. Judging from the judge's consideration in seeing the case of the defendant Carolina Umarela by looking at things that were burdensome.
\end{abstract}

Keywords: Existencing; Judge; Narcotic; Criminal.

\section{Introduction}

The Constitution of the Republic of Indonesia 1945 has provided the basics for state administration and the arrangement of democratic national life. This is reflected in the recognition of people's sovereignty which is implemented according to Constitution of the Republic of Indonesia 1945 as stated in the formulation of Article 1 paragraph (2) of Constitution of the Republic of Indonesia 1945 and the affirmation that the State of Indonesia is a state based on law in accordance with Article 1 paragraph (3). The Constitution of the Republic of Indonesia 1945. The affirmation of this constitutional provision means that all aspects of life in society, state and government must always be based on law. ${ }^{1}$ To realize a rule of law, one of which requires a legal instrument that is used to regulate balance and justice in all areas of life and people's livelihoods through statutory regulations without neglecting the function of jurisprudence. This shows that laws and regulations have an important role in the constitutional state of Indonesia.

The development of science and technology that is taking place today has a significant impact on human life which causes changes in people's lives that can lead to an increase in crime. One type of crime that is rife today is the case of

1Darmoko Yuti Witanto Dan Arya Putra Negara Kutawaringin, 2013, Diskresi Hakim Sebuah Instrumen Menegakkan Keadilan Substantif Dalam Perkara-Perkara Pidana, Cv. Alfabeta, p.1 
narcotics abuse which is not only a problem for the Indonesian people, but has even become a problem in every country in the world. ${ }^{2}$ The rise of narcotics abuse which was initially only for medical purposes as an antidote and painkiller, as well as in the development of science, has now been misused by various groups. ${ }^{3}$

Despite narcotics useful for medical and scientific purposes, but if it is misused or not in accordance with medical instructions it will cause negative effects on the body of the wearer so that it has a very detrimental impact on individuals and society so that it can result in a greater danger to the life and cultural values of the nation which in turn can weaken national resilience. ${ }^{4}$

The increase in narcotics crime shows that narcotics abuse is not only focused on urban areas, but has also spread to all corners of the country ${ }^{5}$ So it can almost be said that there are no areas in Indonesia that are immune to the circulation and abuse of these addictive substances. ${ }^{6}$ Drug abuse is not limited to the wealthy elite. ${ }^{7}$ However, it has penetrated into groups of people who have barely enough income, this has become a question that has a tone of concern whether narcotics abuse is part of the nation's culture or more concretely whether the use of narcotics has become part of the life of Indonesian society. ${ }^{8}$

Someone who has become a drug abuser or addict can participate in medical rehabilitation and or may also be sentenced in accordance with the provisions stipulated in Act No. 35 of $2009 .{ }^{9}$ The sentence given for narcotics abuse varies according to the indictment of the public prosecutor and the legal facts revealed in the trial as long as it does not deviate from the laws and regulations used. ${ }^{10}$ The judge has a consideration which becomes the reason for the judgment given and how long the imprisonment will be imposed on the defendant. The freedom that a judge has is not absolute, therefore there are minimum and maximum penal provisions for the sentence to be imposed on the accused in accordance with the

\footnotetext{
${ }^{2}$ Herlina Martono dan Satya Joewana, 2008, Belajar Hidup Bertanggungjawab, Menangkal Narkotika dan Kekerasan, Balai Pustaka, Jakarta, p. 26.

${ }^{3}$ Haryono Sanadi, Analisis Putusan Hakim Nomor: 113/Pid.B/2007/PN. Pml, Tentang Tindak Pidana Penyalahgunaan Narkotka, Jurnal Dinamika Hukum, Vol. 10 Nomor 1 January 2010, p. 9

${ }^{4}$ A.R Sujono dan Bony Daniel, 2013, Komentar dan Pembahasan Undang-Undang Nomor 35 Tahun 2009 tentang Narkotika, Jakarta: Sinar Grafika,p. 59

${ }^{5}$ Siswandi, 2011, Pangsa Narkotika Dunia Indonesia, Jakarta, Gramedia, p. 16

${ }^{6}$ Kusno Adi, 2009, Diversi Sebagai Upaya Alternatif Penaggulangan Tindak Pidana Narkotika Oleh Anak, UM Press, Malang, p. 4.

${ }^{7}$ Rendy Surya Aditama, Umar Ma'ruf, dan Munsharif Abdul Chalim, Kebijakan Hukum Pidana Terhadap Anak Sebagai Pelaku Kejahatan Psikotropika Di Kepolisian Resor Magelang, Jurnal Daulat $\begin{array}{lllll}\text { Hukum, } & \text { Vol.1 } & \text { March } & \text { 2018, }\end{array}$ http://jurnal.unissula.ac.id/index.php/RH/article/view/2625/1974

${ }^{8}$ Muntaha, Aspek Yuridis Penyalahgunaan Narkotika di Kalangan Remaja, Jurnal Mimbar Hukum, Volume 23, Nomor 1, Februari 2011, p. 211-212.

9 Defry Dwi Irmawan, dan Anis Mashdurohatun, Disparities Criminal Case Against Judge's Decision In Crime Of Narcotics Abuse Viewed From The Purpose Of Criminal Law, Jurnal Daulat Hukum, Vol.1 No.4, December 2018, url: http://jurnal.unissula.ac.id/index.php/RH/article/view/4141/2891

${ }^{9}$ Dafit Supriyanto Daris Warsito, Sistem Pemidanaan Terhadap Pelaku Tindak Pidana Penyalahguna Narkotika, Jurnal Daulat Hukum, Vol.1 No.1, March 2018, url: http://jurnal.unissula.ac.id/index.php/RH/article/view/2562/1919 ${ }^{10}$ Ibid.
} 
provisions of the law. Freedom that is not absolute is a very important thing to prevent arbitrariness and important in ensuring legal certainty.

On process judiciary with the judge as the central point is the main and crucial aspect of a judge in achieving justice. In deciding a case, a Judge must be able to carefully and fairly consider the application of the dimensions of the Law on the one hand with justice that rests on the norms that live in a society on the other. The judge cannot impose a norm that is no longer relevant to be applied in a society, so the judge must be able to explore the legal values that live in a society. If a judge in adjudicating a concrete case still insists on applying a norm that is no longer relevant, injustice will arise.

\section{Research Methods}

To conduct a study in this study the author uses the method sociological juridical. Sociological juridical research is research on legal identification and legal effectiveness. The research specification is carried out using a descriptive analytical approach, namely describing and analyzing data systematically with the intention of providing data as accurate as possible about humans, circumstances and other symptoms. The data used for this research are primary and secondary data. Primary data is data obtained directly from the field or from the first source and has not been processed by other parties. Then secondary data is data obtained from library research consisting of primary legal materials, secondary legal materials and tertiary legal materials.

\section{Results And Discussion}

\subsection{The Existence of Judges in the Implementation of the Court of Narcotics Offenders}

Judges are officials who carry out the duties of judicial power. Judges are state judicial officials who are authorized by law to judge (Article 1 point 8 of the Criminal Procedure Code). Meanwhile, the term judge means a person adjudicating a case in court or the Court; Judge also means court, if the person says "the case has been submitted to the judge". In Article 1 point 8 of the Criminal Procedure Code, it is stated that a judge is a state court authorized by law to adjudicate, adjudicating is a series of actions by a Judge to accept, examine and decide criminal cases based on the principles of freedom, honesty and impartiality in court in matters and according to the manner regulated in law. ${ }^{11}$

The judge's decision is the culmination of a criminal case examination in the entire criminal justice process. In the judge's decision, it is hoped that there will be a reflection of the values of justice and essential truth, human rights, an established, competent and factual control of the law and facts. The judge's decision reflects the visualization of ethics, mentality, morality, the judge's

\footnotetext{
${ }^{11}$ Anonim, 2014, Himpunan Lengkap KUHPer (Kitab Undang-Undang Hukum Perdata), KUHP (Kitab Undang-Undang Hukum Pidana), KUHAP (Kitab Undang-Undang Hukum Acara Pidana), Jakarta, Laksana, p. 576
} 
conscience, as well as being accountable to the science of law or legal doctrine, society, and "For Justice Based on the One Godhead".12

Judges are basically free to interpret the provisions of the law on a legal issue that is presented to the judge before the court including the authority to interpret the criminal provisions in the narcotics crime law which are then manifested in the judges' task decisions normatively regulated in Act No. 48 of 2009 concerning Judicial Power. ${ }^{13}$

In this case the authors conducted research based on the decision of the Magelang District Court on the decision of case Number 70 / Pid.Sus / 2018 / PN.Mgg which shows cases related to the defendant being processed by the court in cases of selling, buying, receiving, being an intermediary in the sale and purchase of Narcotics. The case is analyzed by presenting a series of decisions in the trial which shows the existence of judges in implementing law enforcement against narcotics crimes.

That, on Friday 17 February 2017 at around 10:00 am the defendant ordered Puji Lestari known as Wella by telephone to pick up crystal methamphetamine from Aris (DPO Police) in Semarang, then Puji Lestari known as Wella invited Yudha Pratama to go to Semarang using a Toyota car. Avanza gray Metallic Nopol AA 8594 CA while the defendant remained in Magelang to transfer money to Aris (Police DPO) through Account No. 7895309460 an Nidia Aulia of IDR 18,400,000, (eighteen million four hundred thousand rupiah) for the purchase of these 20 grams of methamphetamine narcotics. Then around 19.00 WIB at the Gayamsari gas station, Semarang city, ${ }^{14}$

At around 19.30 WIB, Police officers from the Central Java Regional Police managed to secure and search the defendant at $* * * * * * * * * * * * * * * * *$, Jurangombo Village, South Magelang, Magelang City so that they managed to find 1 (one) Samsung Duos brand HP type SM-B310E white color along with the simcard No. 085875469469 and 1 (one) slip of proof of ATM BCA Transfer to account. 7895309460 in the name of Nidia Aulia obtained from under the front desk the defendant sat down, 1 (one) BCA Passport ATM number 601900265705 3205, 1 (one) bong made from a baby bottle of Huki brand with a glass dropper and color straw green, 2 (two) glass pipettes, 1 (one) green gas lighter, 1 (one) black CHQ HWH Pocket Scale electric scale, 5 (five) small plastic clip packs, 1 (one) piece of green straw with white stripe, 1 (one) piece of blue straw with white stripe, 1 (one) piece of clear straw with white and red stripes, all of which were found by the officer in a white cloth bag that reads Holland who was at the front desk, the defendant sat down at around 20.30 WIB when Puji Lestari known as Wella arrived at Jl. *******************.15

That the defendant and Puji Lestari known as Wella agreed to buy, accept, become an intermediary in the sale and purchase of the Narcotics and Puji Lestari known as Wella received a wage of between IDR 200,000, - (two hundred

\footnotetext{
12 Widodo Pajar, 2013, Menjadi Hakim Progresif, Indeph Publishing, Bandar Lampung, p. 37-38.

13 Interview with Francisca Widiastuti, SH.M.Hum, Judge at Magelang District Court, on June 29, 2020 at 10.30 WIB

14 Decision on Case Number 70 / Pid.Sus / 2018 / PN.Mgg

15 Ibid.
} 
thousand rupiah) up to IDR 300,000, - (three hundred thousand rupiah) from the defendant apart from that the defendant together with Puji Lestari known as Wella could use the methamphetamine for free and the defendant and Puji Lestari known as Wella did not have valid permission from the authorities and were not intended for the benefit of scientific development and technology. ${ }^{16}$

To find out how the existence (which in this case means the role) of judges cannot be separated from the constitution and other laws and regulations. Judges who are the most important part of the judiciary according to the 1945 Constitution are given the authority to exercise judicial power, namely the power to administer the judiciary in order to enforce law and justice. This is reaffirmed in Act No. 8 of 2004 and Act No. 49 of 2009 concerning General Courts, that court judges are officials who carry out judicial power duties.

In the verdict given to the defendant after considering all aspects from the prosecution to the judge's consideration based on the facts at trial, the judge in the narcotics crime case Number 70 / Pid.Sus / 2018 / PN Mgg with due regard to Article 114 paragraph (2) Jo. Article 132 paragraph (1) Act No. 35 of 2009 concerning Narcotics and Act No. 8 of 1981 concerning Criminal Procedure Law and other relevant laws and regulations shall be tried in the form of: 17

- To declare that the above mentioned Defendant Carolina Umarela Binti Kusno Umarela has been legally and convincingly proven guilty of committing a criminal conspiracy against the law of selling, buying, receiving, being an intermediary in the sale and purchase of Narcotics Category I as in the indictment Primair the Public Prosecutor;

- Imposing the punishment to the Defendant is therefore punishable by imprisonment for 10 (ten) years;

- Imposing the Defendant is also punishable by a fine of Rp1,000,000,000.00 (one billion rupiah);

- To stipulate that if a fine is not paid, it will be replaced by imprisonment for 3 (three) months;

- To determine the period of arrest and detention that the Defendant has served in case Number 34 / Pid.Sus / 2017 / PN.Mgg is deducted entirely from the sentence imposed;

- Determine evidence in the form of:

- 1 (one) white Samsung Duos type SM-B310 cellphone with a simcard No. 085875469469;

- 1 (one) BCA Passport ATM number 601900265705 3205;

- 1 (one) proof of BCA ATM Transfer slip to account 7895309460 in the name of Nindia Aulia;

- 1 (one) bong made from a Huki brand baby pacifier bottle with a green straw;

- 2 (two) glass pipettes;

- 1 (one) green gas lighter;

- 1 (one) black electric scale CHQ HWH Pocket Scale brand;

- 5 (five) Pack of small plastic clips;

16 Ibid.

17 Ibid. 
- 1 (one) piece of green straw with white stripe;

- 1 (one) piece of blue straw with white stripe;

- 1 (one) piece of clear straw with white and red stripes;

- 1 (one) white cloth bag bearing the inscription of Holland;

- Urine as much as + $25 \mathrm{cc}$, which after being examined by the Forensic Laboratory the rest is 1 (one) plastic tube used for urine;

- 1 (one) white SAMSUNG brand type GT-E1272 mobile phone with the SIM card No. 08157775474;

- Urine as much as + $25 \mathrm{cc}$, which after being examined by the Forensic Laboratory the rest is 1 (one) plastic tube used for urine;

- glass pipette with crystal powder weighing \pm 0.003 gram, which after being examined by the Forensic Laboratory, the rest is in the form of crystal powder in a glass pipette with a net weight of 0.002 gram of crystal powder;

- 2 (two) packages of crystal powder in a small plastic clip wrapped in a packet of Gudang Garam Surya cigarettes weighing + 29.351 grams, which after being examined by the Forensic Laboratory, the rest is in the form of crystal powder with a net weight of 29.340 grams of crystal powder;

- (one) Toyota AVANZA metallic gray car with Registration number AA 8594 WK

- Charged the Defendant with a court fee of IDR 2,000 (two thousand rupiah).

According to Francisca Widiastuti, the application of criminal sanctions by judges against perpetrators of criminal acts of narcotics abuse is essentially, the policy of formulating criminal sanctions for Narcotics Abuse in the Indonesian Narcotics Law substantially in this study emphasizes violations of the Narcotics Law. Formulative policies are policies that are strategic and determine, because errors in legislative policies will affect the applicable or judicial policies. Judging from the optics of material criminal law, Act No. 35 of 2009 concerning Narcotics has several types of criminal sanctions formulation systems. ${ }^{18}$

In the application of criminal sanctions against narcotics offenders at the Magelang District Court that the process begins with the Public Prosecutor's indictment (usually the articles charged are in the form of subsidiary, namely the primary indictment, namely Article 114 paragraph (2) Jo. Article 132 paragraph (1) of Act No. 5 of 2009 and subsidiary namely Article 112 paragraph (2) in conjunction with Article 132 paragraph (1) of Act No. 5 of 2009 then the legal facts found will determine whether the position of the defendant is included in one of the appropriate articles. The judge will sentence the defendant proven based on legal facts and articles charged by the prosecutor.

In the Narcotics Law it feels appropriate to be based on considerations in this case the cumulative-alternative formulation system is a formulation system pattern which is directly a combination characterized by nuances of legal certainty (rechts-zekerheids) and nuances of justice. ${ }^{19}$ With the starting point of the combination of the nuances of justice and legal certainty (rechts-zekerheids), the

\footnotetext{
${ }^{18}$ Interview with Francisca Widiastuti, SH.M.Hum, Judge at Magelang District Court, on June 29, 2020 at 10.30 WIB

${ }^{19}$ Eddy O.S. Hiariej, 2015, Prinsip-Prinsip Hukum Pidana, Cahaya Atma Pustaka, Yogyakarta, p. 2425
} 
main characteristic of this formulation system in its applicable policy is that it is flexible and accommodative. ${ }^{20}$

It is not easy to fulfill this need, it can only be fulfilled by a judge with an open mind and eyes. A judge who always involves creativity (logos), initiative (ethos) and feeling (pathos) in his life and life. ${ }^{21}$ The existence of judges in the implementation of the narcotics crime court based on the analysis in case Number 70 / Pid.Sus / 2018 / PN Mgg, is not wrong to be categorized as someone who thinks scientifically. This means that even though judges are in the professional world, what is done is not solely in the framework of professionalism but also in the scientific framework, as seen in decision making, where judges do not merely work to make and determine decisions by looking and applying them unanimously. Round about legal rules that are abstract in nature, but the judge always sees the problems faced in a broader context. ${ }^{22}$

Judges in case Number 70 / Pid.Sus / 2018 / PN Mgg saw the legal rules they faced did not see them as abstract and as they were as written, but saw them as processes whose content and formulation could change from time to time according to conditions and demands for a sense of community justice. ${ }^{23}$

\section{Closing}

The existence of judges in the implementation of the narcotics crime court based on the analysis in case Number 70 / Pid.Sus / 2018 / PN Mgg, is not wrong to be categorized as someone who thinks scientifically. This means that even though judges are in the professional world, what is done is not solely in the framework of professionalism but also in the scientific framework, as seen in decision making, where judges do not merely work to make and determine decisions by looking and applying them unanimously. Round about legal rules that are abstract in nature, but the judge always sees the problems faced in a broader context. The Suggestions are : It is necessary to improve Act No. 35 of 2009 concerning Narcotics, especially those that regulate criminal sanctions so that in imposing criminal sanctions the judge considers elements outside the provisions stipulated in the law such as: age, gender, and background as back family or in the process of education or still in school; It is hoped that the panel of judges will consider more about the rehabilitation aspect for narcotics abuse which has been enacted by the Supreme Court Circular (SEMA) Number 4 of 2010 concerning Placement of Narcotics Abuse into Medical and Rehabilitation Institutions (not dealers) so that the use of narcotics after being rehabilitated will be able to return. and are accepted in people's lives well and do not repeat their actions; It is expected that judges in carrying out their judicial duties will be carried out professionally as much as possible for the sake of eradicating narcotics abuse.

\section{References}

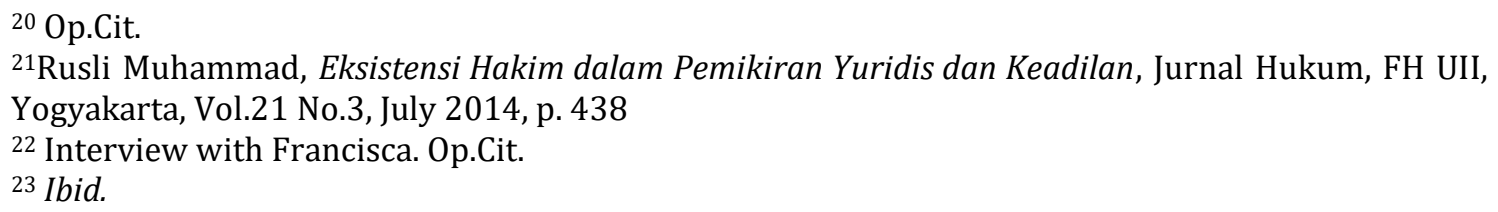


Books

[1] A.R Sujono dan Bony Daniel, 2013, Komentar dan Pembahasan UndangUndang Nomor 35 Tahun 2009 tentang Narkotika, Jakarta: Sinar Grafika

[2] Anonim, 2014, Himpunan Lengkap KUHPer (Kitab Undang-Undang Hukum Perdata), KUHP (Kitab Undang-Undang Hukum Pidana), KUHAP (Kitab Undang-Undang Hukum Acara Pidana), Jakarta, Laksana

[3] Eddy O.S. Hiariej, 2015, Prinsip-Prinsip Hukum Pidana, Cahaya Atma Pustaka, Yogyakarta

[4] Widodo Pajar, 2013, Menjadi Hakim Progresif, Indeph Publishing, Bandar Lampung

[5] Darmoko Yuti Witanto Dan Arya Putra Negara Kutawaringin, 2013, Diskresi Hakim Sebuah Instrumen Menegakkan Keadilan Substantif Dalam PerkaraPerkara Pidana, Cv. Alfabeta

[6] Herlina Martono dan Satya Joewana, 2008, Belajar Hidup Bertanggungjawab, Menangkal Narkotika dan Kekerasan, Balai Pustaka, Jakarta

[7] Kusno Adi, 2009, Diversi Sebagai Upaya Alternatif Penaggulangan Tindak Pidana Narkotika Oleh Anak, UM Press, Malang

[8] Siswandi, 2011, Pangsa Narkotika Dunia Indonesia, Jakarta, Gramedia

\section{Regulation}

Decision on Case Number 70 / Pid.Sus / 2018 / PN.Mgg

\section{Journals and Documents}

[1] Dafit Supriyanto Daris Warsito, Sistem Pemidanaan Terhadap Pelaku Tindak Pidana Penyalahguna Narkotika, Jurnal Daulat Hukum, Vol.1 No.1, March 2018, url: http://jurnal.unissula.ac.id/index.php/RH/article/view/2562/1919

[2] Defry Dwi Irmawan, dan Anis Mashdurohatun, Disparities Criminal Case Against Judge's Decision In Crime Of Narcotics Abuse Viewed From The Purpose Of Criminal Law, Jurnal Daulat Hukum, Vol.1 No.4, December 2018, url: http://jurnal.unissula.ac.id/index.php/RH/article/view/4141/2891

[3] Haryono Sanadi, Analisis Putusan Hakim Nomor: 113/Pid.B/2007/PN. Pml, Tentang Tindak Pidana Penyalahgunaan Narkotka, Jurnal Dinamika Hukum, Vol. 10 Nomor 1 January 2010, P. 9

[4] Muntaha, Aspek Yuridis Penyalahgunaan Narkotika di Kalangan Remaja, Jurnal Mimbar Hukum, Volume 23, Nomor 1, Februari 2011

[5] Rendy Surya Aditama, Umar Ma'ruf, dan Munsharif Abdul Chalim, Kebijakan Hukum Pidana Terhadap Anak Sebagai Pelaku Kejahatan Psikotropika Di Kepolisian Resor Magelang, Jurnal Daulat Hukum, Vol.1 No.1 March 2018, url: http://jurnal.unissula.ac.id/index.php/RH/article/view/2625/1974

[6] Rusli Muhammad, Eksistensi Hakim dalam Pemikiran Yuridis dan Keadilan, Jurnal Hukum, FH UII, Yogyakarta, Vol.21 No.3, July 2014

\section{Interview:}

[1] Interview with Francisca Widiastuti, SH.M.Hum, Judge at Magelang District Court, on June 29, 2020 at 10.30 WIB 
Volume 2 Issue 3, September 2020, (323 - 330) 